\title{
Activity of antiretroviral drugs in human infections by opportunistic agents
}

\author{
Izabel Galhardo Demarchi' ${ }^{1}$ Daniela Maira Cardozo ${ }^{2}$, Sandra Mara Alessi Aristides', \\ Ricardo Alberto Moliterno ${ }^{2}$, Thaís Gomes Verzignassi Silveira ${ }^{1}$, Rosilene Fressatti Cardoso ${ }^{1}$, \\ Dennis Armando Bertolini ${ }^{1}$, Terezinha Inez Estivalet Svidzinski ${ }^{1}$, Jorge Juarez Vieira Teixeira ${ }^{1}$, \\ Maria Valdrinez Campana Lonardoni ${ }^{1, *}$
}

\author{
${ }^{1}$ Department of Clinical Analysis and Biomedicinea, State University of Maringá, ${ }^{2}$ Department of Basic Health Sciences, \\ State University of Maringá
}

\begin{abstract}
Highly active antiretroviral therapy (HAART) is used in patients infected with HIV. This treatment has been shown to significantly decrease opportunist infections such as those caused by viruses, fungi and particularly, protozoa. The use of HAART in HIV-positive persons is associated with immune reconstitution as well as decreased prevalence of oral candidiasis and candidal carriage. Antiretroviral therapy benefits patients who are co-infected by the human immunodeficiency virus (HIV), human herpes virus 8 (HHV-8), Epstein-Barr virus, hepatitis B virus (HBV), parvovirus B19 and cytomegalovirus (CMV). HAART has also led to a significant reduction in the incidence, and the modification of characteristics, of bacteremia by etiological agents such as Staphylococcus aureus, coagulase negative staphylococcus, non-typhoid species of Salmonella, Streptococcus pneumoniae, Pseudomonas aeruginosa, and Mycobacterium tuberculosis. HAART can modify the natural history of cryptosporidiosis and microsporidiosis, and restore mucosal immunity, leading to the eradication of Cryptosporidium parvum. A similar restoration of immune response occurs in infections by Toxoplasma gondii. The decline in the incidence of visceral leishmaniasis/HIV co-infection can be observed after the introduction of protease inhibitor therapy. Current findings are highly relevant for clinical medicine and may serve to reduce the number of prescribed drugs thereby improving the quality of life of patients with opportunistic diseases.
\end{abstract}

Uniterms: Highly active antiretroviral therapy. Antiretroviral drugs/activity. Opportunist infections/treatment.

A terapia HAART (terapia antirretroviral altamente ativa) é usada em pacientes infectados pelo vírus da imunodeficiência humana (HIV) e demonstrou diminuição significativa de infecções oportunistas, tais como as causadas por vírus, fungos, protozoários e bactérias. O uso da HAART está associado com a reconstituição imunológica e diminuição na prevalência de candidíase oral. A terapia antirretroviral beneficia pacientes coinfectados pelo HIV, vírus herpes humano 8 (HHV-8), vírus Epstein-Barr (EBV), vírus da hepatite B (HBV), parvovírus B19 e citomegalovírus (CMV). A HAART também apresentou redução significativa da incidência e modificou as características da bacteremia por agentes etiológicos, tais como Staphylococcus aureus, espécies não-tifóides de Salmonella, Streptococcus pneumoniae, Pseudomonas aeruginosa, Mycobacterium tuberculosis. A HAART é capaz de modificar significativamente a história natural da criptosporidiose e microsporidiose. HAART pode efetivamente restaurar a imunidade da mucosa, levando à erradicação de Cryptosporidium parvum. Semelhante restauração da resposta imune ocorre em infecções por Toxoplasma gondii. O declínio na incidência de co-infecção leishmaniose visceral/HIV pode ser observada após a introdução da terapia com inibidores da protease. Os resultados atuais são altamente relevantes para a medicina clínica e podem proporcionar diminuição no número de prescrições medicamentosas e, consequentemente, melhor qualidade de vida para pacientes com doenças oportunistas.

Unitermos: Terapia antirretroviral altamente ativa. Medicamentos antirretrovirais/atividade. Infecções oportunistas/tratamento.

\footnotetext{
*Correspondence: M. V. C. Lonardoni. Universidade Estadual de Maringá. Avenida Colombo, 5790 - 87020-900 - Maringá - PR, Brasil. E-mail: mvclonardoni@uem.br.
} 


\section{INTRODUCTION}

Combined antiretroviral (ARV) drugs have improved survival rates in acquired immune deficiency syndrome (AIDS) patients. Early antiretroviral drugs caused only temporary gains due to low efficiency in the recovery of immune competence of the patient and to the limited effects in reducing viral load. The use of new ARV classes (protease inhibitors and non-nucleoside reverse transcriptase inhibitors) from the mid-1990s proved highly successful in HIV-infected persons through highly active antiretroviral therapy (HAART). A significant fall in AIDS morbidity and mortality rates were reported (Delpierre et al., 2008).

In developed countries, HAART has achieved significant results in the suppression of HIV viral load and restoration of immunity, coupled with improvements in qualitative and quantitative CD4+ T-cells counts and with significant decreases in opportunist infections such as those caused by viruses, fungi and particularly, protozoa. Standout medicines include reverse transcriptase nucleosides inhibitors and protease inhibitors (WHO, 2006).

Protease inhibitors block the activity of the aspartyl protease of the HIV and may affect the growth of other micro-organisms besides blocking virus multiplication (Abbenante, Fairlie, 2005). The activity of HIV protease inhibitors in Leishmania spp. (Savoia, Allice, Tovo, 2005), Toxoplasma gondii (Deuroin, Santillana-Hayat, 2000), Plasmodium spp. (Andrews et al., 2006; Parikh et al., 2005; Redmond et al., 2007), Crypstosporidium parvum (Mele et al., 2003; Pozio, Morales, 2005), Candida albicans (Falkensammer et al., 2007), and Mycobacterium spp. (Kabbesh et al., 2005), among others, has been previously shown. Reverse transcriptase inhibitors may also affect organisms such as Trypanosoma cruzi (NakajimaShimada, Aoki, 1998).

The current systematic review identifies and analyzes original articles published in the literature on the activity of antiretroviral drugs in human infections by opportunist agents.

\section{METHODS}

A systematic review of the databases PubMed (U.S. National Library of Medicine), SciELO (Scientific Electronic Library Online) and LILACS (Latin American and Caribbean Center on Information in Health Sciences) was undertaken from February to April 2008. This study focused on articles retrieved in English, French, Italian, Spanish and Portuguese languages, published between January 1998 and December 2007. Additional articles besides those identified in the systematic review were included in the discussion of the data.

\section{Search strategy and quality assessment}

The search strategy on PubMed consisted of employing the MeSH Database for the term 'antiretroviral agents' coupled to 'fungi', 'bacteria', 'viruses', 'protozoa', 'opportunistic infections', using the limits of the methodological filter to identify original publications of clinical trials, randomized controlled trials, case reports, classical articles, comparative studies and journal articles. Although a free term search strategy was employed on the SciELO and LILACS databases, coupling 'antiretroviral drugs' and 'fungus', 'bacteria', 'virus', 'protozoa', 'opportunist infections', no reference was extant.

The first stage involving the bibliography focused on sample quality and quality of the analysis among identified publications. Two researchers independently undertook the same task on the electronic databases in order to increase search precision.

The second stage consisted of an analysis of potential articles by four independent researchers. This entailed examination of each article's predefined contents, namely, aim, opportunist agent, study design, antiretroviral drugs, conclusion. Publications were chosen at random and allocated to the four researchers for analysis. In addition, an additional search for relevant articles identified from the list of references of the initially retrieved papers was performed.

The third stage involved a further final randomized selection of article handed out to three researchers, or 'independent judges,' for verification of the total percentage of agreement with regard to contents from each article versus the four researchers' predefined items.

\section{Behavioral data}

Figure 1 shows the potential publications for analysis by the current study. The 25 articles identified only on the PubMed database using the key word antiretroviral agent and the terms fungi, viruses, bacteria, protozoa were combined in 6, 9, 5 and 5 publications, respectively. Antiretroviral combinations and opportunist infections/infectious were automatically classified for the respective opportunist agent group. Total percentage concordance among the three judges with regard to the four independent researchers was calculated as $72.7 \%(8 / 11), 75.0 \%(3 / 4)$ and $77.8 \%(7 / 9)$.

\section{Antiretroviral drugs and fungal agents (Table I)}

HAART has produced satisfactory results in HIV 

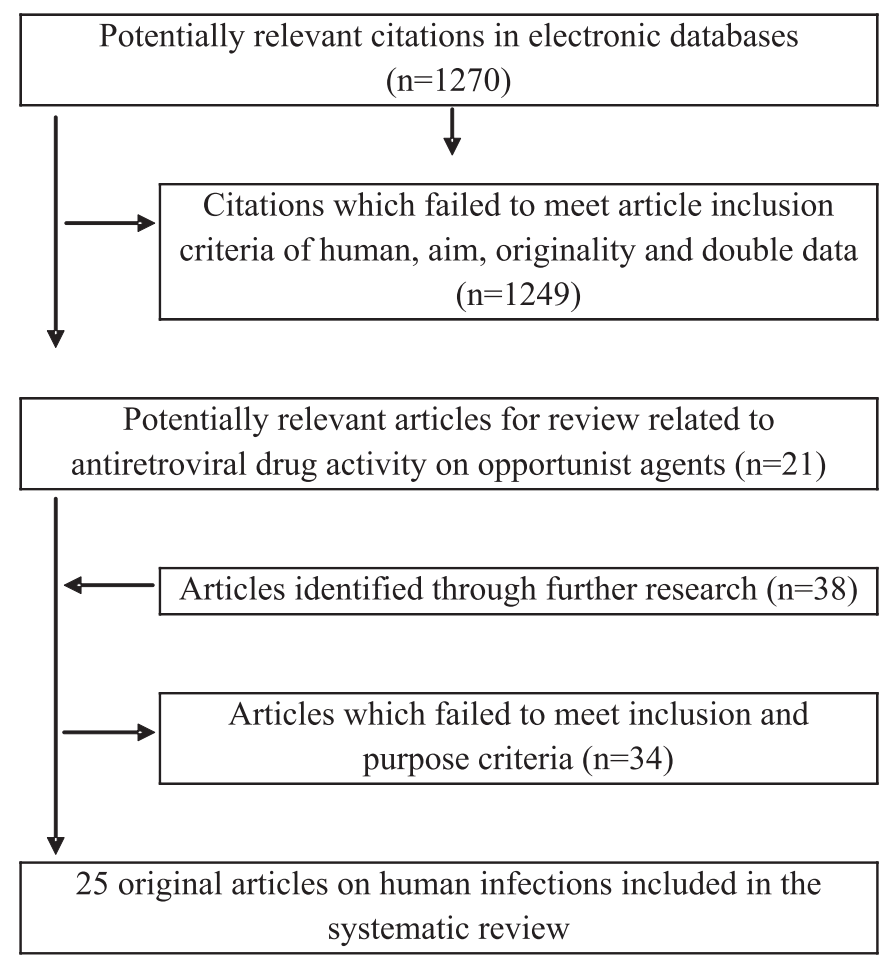

FIGURE 1 - Flow of studies for systematic review.

patients also infected by Candida spp. Since oral candidiasis (OC) is a particularly common infection in this patient group, it is noteworthy that HAART significantly decreases the amount of fungi in the oral cavity (Macura et al., 2002). A decrease in the prevalence of OC has also been coupled with a rise in CD4+ T-cell counts (Yang et al., 2006). The diminished exposure to Candida spp. was accompanied by decreases in levels of Candida-specific secretory immunoglobulin A (Pomarico, 2009).

In addition, the importance of secreted aspartic protease (SAP), an important virulence factor of Candida spp, has also been emphasized. HIV protease inhibitor, a common component of HAART, is an inhibitor of HIV protease, the enzyme required for correct processing of HIV's retroviral precursor proteins. Previous research has evaluated the inhibitory activity of protease inhibitors (PI) for SAP during OC manifestations. The anti-SAP effect of PI-HAART (indinavir and ritonavir) has been associated with the clinical resolution of $\mathrm{OC}$ but not with late and inconstant recovery of anticandidal cellular immunity (Cassone et al., 2002). Although oral candidal isolates secrete protease, ritonavir does not inhibit all protease-secreting oral yeast isolates. Nevertheless, it decreases the percentage of Candida spp. isolates, particularly C. albicans, which is resistant to anti-fungal agents (amphotericin B, fluorocitosine, fluoconazole, ketoconazole and itraconazole). This is perhaps due to the synergic effect between these drugs and antiretrovirals (Migliorati et al., 2004).

Antiretroviral treatment, including protease inhibitors, in patients with advanced HIV infection, has a positive impact on the natural history of oropharyngeal candidiasis (OPC). This positive impact appears to be correlated with improved immunological function in spite of constant HIV replication (Arribas et al., 2000). Consequently, decrease in colonization and oral manifestations has been reported in patients, with high CD4+ T-cell counts reported after PI employment (Hoegl et al., 1998).

The same protease inhibitors can act directly on SAPs 1, 2 and 3, but not on SAPs 4, 5 and 6, inhibiting several relevant biological processes of $C$. albicans, such as growth and adhesion to mammalian cells (Bektic et al., 2001; Blanco et al., 2003; Borg-von Zepelin et al., 1999; Braga-Silva et al., 2010; Cassone et al., 1999; Falkensammer, Pilz, Bektic, 2007; Gruber et al., 1999; Korting et al., 1999; Monod et al., 1999). Braga-Silva et al. (2010) showed that amprenavir reduced the expression of surface mannose- and sialic acid-rich glycoconjugates also inhibited esterase activity, sterol content and biofilm formation in C. albicans. The adhesion of Candida sp. may be related to surface glycoprotein or ion-bridging, especially with calcium ions, given these physical factors may be affected differentially by different protease inhibitors (Tsang, Hong, 2009).

In summary, it is possible to conclude that the use of antiretroviral therapy in HIV-positive was associated with immune reconstitution as well as decreases in the prevalence of $\mathrm{OC}$ and candidal carriage. According to Pomarico et al. (2009), the protease inhibitors might have had an anti-candidiasis effect, resulting not only from immune reconstitution, but also from direct anti-yeast mechanisms.

\section{Antiretroviral drugs and viral agents (Table II)}

Antiretroviral therapy benefits patients who are co-infected by HIV, HHV-8 (Harrington et al., 1997; Hocqueloux et al., 2001; Lebbe et al., 1998; Wit, Sol, Renwick, 1998), EBV (Hocqueloux et al., 2001), HBV (Benhamou et al., 2001; Deal et al., 2002; Perillo et al., 2000), parvovirus B19 (Mylonakis et al., 1999; Ware, Moore, 2001) and CMV (Borges et al., 2001; Deayton et al., 1999; Li et al., 1999).

It has been shown that HIV stimulates HHV-8 replication in vitro (Harrington et al., 1997) and strong suppression of HIV replication by antiretroviral agents may thus indirectly suppress HHV-8. After 94 weeks of HAART treatment, a case report detected absolute cure from Kaposi sarcoma (KS), DNA clearance of HHV-8 in peripheral blood mononuclear cells and plasma, and an 
TABLE I - Characteristics of studies included in the systematic review, on antiretroviral agents and fungi

\begin{tabular}{|c|c|c|c|c|c|}
\hline Source & Aim & Study design & Drug groups & Patients (n) & Conclusion \\
\hline $\begin{array}{l}\text { Macura et al. } \\
\text { Folia Med. } \\
\text { Cracov., } \\
2002 . \\
\end{array}$ & $\begin{array}{l}\text { Evaluate impact of } \\
\text { antiretroviral therapy on } \\
\text { development of oral mucosa } \\
\text { mycosis in HIV patients. }\end{array}$ & $\begin{array}{l}\text { Controlled } \\
\text { clinical trial }\end{array}$ & $\begin{array}{c}\text { PI } \\
\text { NNRTI }\end{array}$ & 75 & $\begin{array}{l}\text { ARV in HIV patients } \\
\text { significantly reduced the number } \\
\text { of fungi present in oral cavity. }\end{array}$ \\
\hline $\begin{array}{l}\text { Yang et } \\
\text { al. BMC } \\
\text { Infectious } \\
\text { Disease, } \\
2006 . \\
\end{array}$ & $\begin{array}{l}\text { Determine effect of prolonged } \\
\text { HAART on oropharyngeal } \\
\text { candidiasis and colonization } \\
\text { with Candida species in } \\
\text { Taiwan. }\end{array}$ & Prospective & HAART & 142 & $\begin{array}{l}\text { HAART was highly effective for } \\
\text { decreasing oral candidiasis in } \\
\text { association with a rise in CD4+ } \\
\text { T-cell count. }\end{array}$ \\
\hline $\begin{array}{l}\text { Cassone et al. } \\
\text { J. Infect. Dis. } \\
2002 \text {. }\end{array}$ & $\begin{array}{l}\text { Compare effects of IP } \\
\text { and NNRTIs in SAP in } C \text {. } \\
\text { albicans. }\end{array}$ & $\begin{array}{l}\text { Cross-sectional } \\
\text { and longitudinal. }\end{array}$ & $\begin{array}{c}\text { PI } \\
\text { NNRTI }\end{array}$ & 60 & $\begin{array}{l}\text { PIs apply an early, immune } \\
\text { reconstitution-independent effect } \\
\text { on Candida virulence in oral } \\
\text { cavities of HIV-positive subjects. }\end{array}$ \\
\hline $\begin{array}{l}\text { Migliorati } \\
\text { et al. } \\
\text { Oral Surg. } \\
\text { Oral Med. } \\
\text { Oral Pathol. } \\
\text { Oral Radiol. } \\
\text { Endod., } 2004 .\end{array}$ & $\begin{array}{l}\text { Evaluate ritonavir's anti- } \\
\text { fungal activities, principally } \\
\text { in oral candidal isolates that } \\
\text { secrete protease. }\end{array}$ & Clinical trial & PI & 19 & $\begin{array}{l}\text { Ritonavir does not inhibit all } \\
\text { protease-secreting oral yeast } \\
\text { isolates. }\end{array}$ \\
\hline $\begin{array}{l}\text { Arribas et al. } \\
\text { AIDS, } 2000 .\end{array}$ & $\begin{array}{l}\text { This study determined } \\
\text { the relationship between } \\
\text { antiretroviral therapy and } \\
\text { changes in prevalence and } \\
\text { amount of oropharyngeal } \\
\text { candidiasis (OPC) and skin } \\
\text { test reactivity for delayed } \\
\text { hypersensitivity type. }\end{array}$ & $\begin{array}{l}\text { Observational } \\
\text { cohort }\end{array}$ & $\begin{array}{c}\text { PI } \\
\text { NRTI }\end{array}$ & 99 & $\begin{array}{l}\text { In patients with advanced HIV } \\
\text { infection, antiretroviral therapy } \\
\text { including a protease inhibitor } \\
\text { has a positive impact on natural } \\
\text { history of OPC. }\end{array}$ \\
\hline $\begin{array}{l}\text { Hoegl et al. } \\
\text { Mycoses, } \\
1998 .\end{array}$ & $\begin{array}{l}\text { Evaluate the effects of } \\
\text { treatment with an HIV } \\
\text { protease inhibitor (PI) on oral } \\
\text { candidiasis. }\end{array}$ & $\begin{array}{l}\text { Retrospective } \\
\text { and prospective }\end{array}$ & $\begin{array}{c}\text { PI } \\
\text { NRTI }\end{array}$ & 62 & $\begin{array}{l}\text { Absence of Candida } \\
\text { colonization and manifest oral } \\
\text { candidiasis was observed only in } \\
\text { patients with elevation of CD4+ } \\
\text { T-cells after PI. }\end{array}$ \\
\hline
\end{tabular}

Protease inhibitor (PI); Nonnucleoside reverse-transcriptase inhibitors (NNRTI); Nucleoside analog reverse-transcriptase inhibitors (NRTI), Highly active antiretroviral therapy (HAART); Antiretroviral therapy (ARV).

improvement in the patient's immunological condition (Wit, Sol, Renwick, 1998). A cohort study with ten patients also showed KS/ DNA clearance of HHV-8 in HIV patients after immune reconstitution with antiretroviral therapy containing a protease inhibitor. Antiretroviral therapy has been effective in KS regression and HHV-8 viraemia negation condition (Lebbe et al., 1998).

Primary effusion lymphoma (PEL) is a rare HIVassociated cancer which may be caused by HHV-8 and EBV infection. A case report of a HAART-treated AIDS patient showed complete PEL clearance and decrease in HHV-8-DNA and EBV-DNA to negligible levels. When chemotherapy is contraindicated, HAART becomes a vi- able alternative (Hocqueloux et al., 2001).

There is evidence that the AZT (azidothymidine) and valganciclovir association design targeting cells with lytic Kaposi sarcoma herpes virus (KSHV) replication also has activity in KSHV- associated multicentric Castleman disease (MCD) (Uldrick et al., 2011). AZT and interferonalpha (IFN- $\alpha$ ) induced apoptosis in HHV-8+/EBV- PEL cells in culture, by induction of a tumor necrosis factorrelated apoptosis inducing ligand (TRAIL) mediated suicide program (Wu et al., 2005).

EBV-associated immunoblastic lymphoma occurs in immunocompromised patients such as those with AIDS where Dewan et al. (2009) observed that ritonavir induced 
TABLE II - Characteristics of studies included in the systematic review, on antiretroviral agents and virus

\begin{tabular}{|c|c|c|c|c|c|}
\hline Source & Aim & Study design & Drug groups & Patients (n) & Conclusion \\
\hline $\begin{array}{l}\text { Wit et al. } \\
\text { AIDS, } 1998 .\end{array}$ & $\begin{array}{l}\text { Describe a case of complete } \\
\text { regression of AIDS-related } \\
\text { KS and clearance of HHV-8 } \\
\text { DNA after initiation of ARV. }\end{array}$ & Case report & NRTI & 1 & $\begin{array}{l}\text { Clearance of HHV-8 DNA } \\
\text { from both peripheral blood } \\
\text { mononuclear cells and plasma } \\
\text { after initiation of antiretroviral } \\
\text { therapy. }\end{array}$ \\
\hline
\end{tabular}

\begin{tabular}{|c|c|c|c|c|c|}
\hline $\begin{array}{l}\text { Lebbé et al. } \\
\text { AIDS, } 1998 .\end{array}$ & $\begin{array}{l}\text { Correlate clinical and } \\
\text { biological response of IP } \\
\text { with HIV-associated Kaposi's } \\
\text { sarcoma. }\end{array}$ & Prospective & $\begin{array}{l}\text { NRTI } \\
\text { PI }\end{array}$ & 10 & $\begin{array}{l}\text { Antiviral therapy with protease } \\
\text { inhibitors is clinically effective } \\
\text { in HIV-associated Kaposi's } \\
\text { sarcoma. }\end{array}$ \\
\hline $\begin{array}{l}\text { Hocqueloux } \\
\text { et al. } \\
\text { AIDS, } 2001 \text {. }\end{array}$ & $\begin{array}{l}\text { Analyze remission of primary } \\
\text { lymphoma effusion in } \\
\text { HAART-subjected patient. }\end{array}$ & Case report & $\begin{array}{c}\text { PI } \\
\text { NRTI NNRTI }\end{array}$ & 1 & $\begin{array}{l}\text { Complete remission of primary } \\
\text { effusion lymphoma. }\end{array}$ \\
\hline $\begin{array}{l}\text { Mylonakis } \\
\text { et al. } \\
\text { Am. J. } \\
\text { Hematol., } \\
1999 .\end{array}$ & $\begin{array}{l}\text { Report on remission of } \\
\text { parvovirus B-19-infected } \\
\text { patient with aplasia, prior to } \\
\text { HAART treatment. }\end{array}$ & Case report & $\begin{array}{c}\text { PI } \\
\text { NRTI }\end{array}$ & 1 & $\begin{array}{l}\text { CD4+ T-cells count } \\
\text { progressively increased, and } \\
\text { DNA polymerase chain reaction } \\
\text { for parvovirus B19 became } \\
\text { undetectable. }\end{array}$ \\
\hline
\end{tabular}

\begin{tabular}{|c|c|c|c|c|c|}
\hline $\begin{array}{l}\text { Ware, Moore. } \\
\text { Clin. Infect. } \\
\text { Dis., } 2001 .\end{array}$ & $\begin{array}{l}\text { Describe solution of chronic } \\
\text { parvovirus B-19-infected } \\
\text { patient with AIDS when } \\
\text { HAART is employed. }\end{array}$ & Case report & $\begin{array}{c}\text { PI } \\
\text { NRTI }\end{array}$ & 1 & $\begin{array}{l}\text { Serologic evidence of } \\
\text { eradication of parvovirus } \\
\text { after having received } \\
\text { effective treatment for human } \\
\text { immunodeficiency virus } \\
\text { infection. }\end{array}$ \\
\hline
\end{tabular}

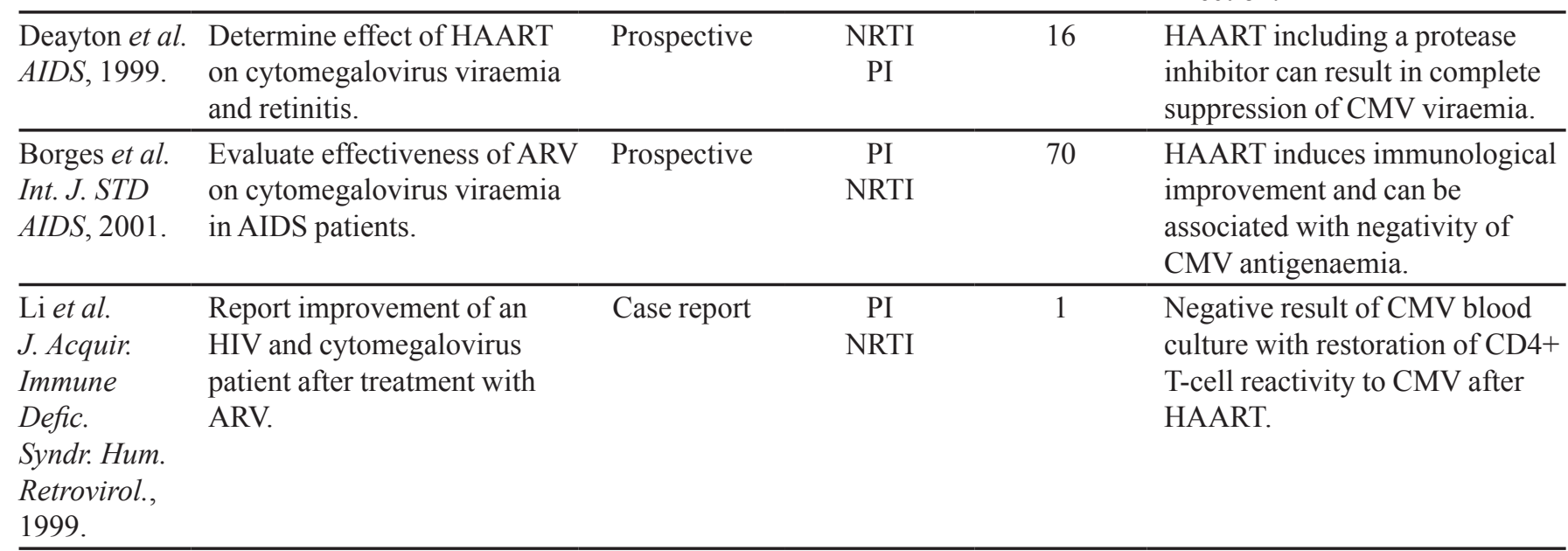

Protease inhibitor (PI); Nonnucleoside reverse-transcriptase inhibitors (NNRTI); Nucleoside analog reverse-transcriptase inhibitors (NRTI), Highly active antiretroviral therapy (HAART), Antiretroviral therapy (ARV).

cell-cycle arrest at the G1-phase as well as apoptosis through down-regulation of cell-cycle gene cyclin D2 and antiapoptotic gene survivin. Furthermore, ritonavir suppressed transcriptional activation of nuclear factorkappaB $(\mathrm{NF}-\kappa \mathrm{B})$ in these cells. AZT inhibits NF- $\kappa \mathrm{B}$ and up-regulates EBV gene expression in primary Epstein-
Barr virus-positive Burkitt lymphoma (EBV-BL) lines (Kurokawa et al., 2005).

Lamivudine (3TC), a nucleoside analogue reverse transcriptase inhibitor of HIV and HBV DNA polymerase, is used in the long-term treatment of HBV chronic hepatitis because of its effectiveness and good tolerability. Research 
with HBV-DNA detection-sensitive techniques has demonstrated the effectiveness of lamivudine in co-infected HIV patients over a long period of time (Deal et al., 2002). However, resistant mutants occur during treatment and also for HIV, corresponding to changes of methionine for isoleucine and valine in the YMDD domain $\mathrm{C}$ sequence of the enzyme (Deal et al., 2002). Other drugs such as tenofovir and adefovir dipivoxil can show beneficial associations with HAART in the treatment of lamivudine-resistant hepatitis B (Benhamou et al., 2001; Perillo et al., 2000). There are potentially more effective drugs or combination therapies, which can reduce intrahepatic covalently closed circular DNA (cccDNA) effectively in chronic B hepatitis patients (Kumar et al., 2011; Reijnders et al., 2010; Shinkai et al., 2006; Sung et al., 2005).

Other studies report virus clearance by parvovirus B19 in HIV-infected people after HAART application. The first case report showed the clearance of parvovirus B19 in a patient with red blood aplasia and severe anemia some two months after the start of antiretroviral therapy, that was not eradicated after conventional treatment with intravenous immunoglobulin (IVIG) (Ware, Moore, 2001). The second study showed that overall clearance in the serum of a parvovirus B19-chronic anemia case occurred after 14 months of HAART. Thus, antiretrovirals can be effective and possibly eliminate transfusions and IVIG therapy in HIV co-infected individuals (Mylonakis et al., 1999). This may be associated with the immune reconstitution syndrome (IRS). In 2005, the first case of IRS associated with B19-induced chronic pure red cell aplasia during highly active antiretroviral therapy was described (Intalapaporn et al., 2005).

HAART use, coupled with PI, may require complete suppression of CMV. This response was correlated with protection against CMV retinitis in a group of patients featuring high risk for the development of the disease (Deyaton et al., 1999). Antiretroviral therapy may also result in negative antigenemia and culture for CMV, immunological improvement through increased CD4+ T-cell count, increase in reactivity of CD4+ T-cells for CMV antigens and reduction in HIV load (Borges et al., 2001; Li et al., 1999). Criteria for discontinuation of treatment for CMV when the patient is receiving HAART for several months requires further investigation by prospective studies $(\mathrm{Li}$ et al., 1999). To our knowledge, there are no articles describing the direct activity of antiretroviral drugs on CMV.

\section{Antiretroviral drugs and bacterial agents (Table III)}

Respiratory tract bacterial (pyogenic and nonpyogenic) infections in human immunodeficiency virus-infected patients are the most frequent respiratory disease but other sites may also be compromised. In the pre-HAART era the incidence of most common opportunistic infections such as bronchitis and pneumonia could be partially prevented by the use of prophylaxis (Mayaud, Parrot, Cadranel, 2002). According to these authors the main pyogenic bacteria responsible for pneumonia in these patients were Streptococcus pneumoniae and, to a lesser degree, Haemophilus influenzae, in adults as well as children in both developed and developing countries. In the HAART era, some studies have observed a decrease in the number of cases of bacterial pneumonia (Mayaud, Parrot, Cadranel, 2002), while other authors (Tumbarello et al., 1999) have shown that this decrease was mainly observed for nosocomial pneumonia and remained nonsignificant for community-acquired pneumonia.

HAART has also led to a significant reduction in the incidence, and in changes of characteristics, of bacteremia by etiological agents such as Staphylococcus aureus (28\%), coagulase negative Staphylococcus (13\%), nontyphoid (NT) species of Salmonella (11\%), Streptococcus pneumoniae (11\%), Pseudomonas aeruginosa (11\%) (Tumbarello et al., 2000). The incidence of Non-typhoidal Salmonella (NTS) and Campylobacter have declined since the introduction of HAART (Larsen et al., 2011). A decline in incidence of nosocomial bacterial pneumonia (NBP) caused by Pseudomonas aeruginosa, Staphylococcus aureus and Streptococcus pneumoniae in HIV-infected individuals was observed after the introduction of HAART. $S$. aureus and $P$. aeruginosa were the leading causes of NBP, but the frequency of pneumococcal pneumonia was also significant (Franzett et al., 2006).

A study carried out at a central hospital in Malawi (Africa) during the period of national scale-up of antiretroviral therapy and cotrimoxazole prophylaxis, demonstrated a downward trend in invasive pneumococcal disease (IPD) (Everett et al., 2011). Although HAART has been associated with significant decline in IPD morbidity and mortality, HIV-infected African children with access to HAART remain a high-risk group for IPD (Nunes et al., 2011).

HIV increases the risk of immediate tuberculosis (TB) progress soon after infection or re-infection with Mycobacterium tuberculosis (MTB) and of reactivating a latent MTB. HAART decreased the incidence of MTB infections and death among patients with AIDS, although some patients experienced temporary worsening of TB (Leone et al., 2010). This phenomenon termed Immune Reconstitution Inflammatory Syndrome (IRIS) is caused by the introduction of HAART, where immune recovery may result in immunological reactions and clinical dete- 
TABLE III - Characteristics of studies included in the systematic review, on antiretroviral agents and bacteria

\begin{tabular}{|c|c|c|c|c|c|}
\hline Source & Aim & Study design & Drug groups & Patients (n) & Conclusion \\
\hline $\begin{array}{l}\text { Kirk et al. } \\
\text { Am. J. Respir. } \\
\text { Crit. Care } \\
\text { Med., } 2000 . \\
\end{array}$ & $\begin{array}{l}\text { Evaluate effectiveness of } \\
\text { HAART in Mycobacterium } \\
\text { tuberculosis and } M \text {. avium- } \\
\text { infected HIV patients. }\end{array}$ & Cohort & HAART & 7,000 & $\begin{array}{l}\text { Decrease in TB was associated } \\
\text { with introduction of HAART and } \\
\text { changes in } \mathrm{CD}^{+} \text {T-cell count. }\end{array}$ \\
\hline $\begin{array}{l}\text { Tumbarello } \\
\text { et al. } \\
\text { Eur. J. Clin. } \\
\text { Microbiol. } \\
\text { Infect. Dis., } \\
2001 . \\
\end{array}$ & $\begin{array}{l}\text { Evaluate effectiveness of } \\
\text { HAART on infection spread } \\
\text { by Mycobacterium avium in } \\
\text { HIV patients. }\end{array}$ & Case-control & HAART & 81 & $\begin{array}{l}\text { MAC infections are less frequent } \\
\text { in HAART era, but remain } \\
\text { responsible for cases of severe } \\
\text { disease. }\end{array}$ \\
\hline $\begin{array}{l}\text { Tumbarello } \\
\text { et al. } \\
\text { J. Acquir. } \\
\text { Immune } \\
\text { Defic. Syndr., } \\
2000 . \\
\end{array}$ & $\begin{array}{l}\text { Evaluate incidence of } \\
\text { bacteremia in HIV-infected } \\
\text { subjects after introduction of } \\
\text { HAART and describe patients' } \\
\text { characteristics. }\end{array}$ & Case-control & $\begin{array}{c}\text { PI } \\
\text { NRTI }\end{array}$ & 174 & $\begin{array}{l}\text { HAART promotes a significant } \\
\text { reduction in the incidence, and } \\
\text { in changes of characteristics, of } \\
\text { bacteremia. }\end{array}$ \\
\hline $\begin{array}{l}\text { Paech et al } \\
\text { Clin. Infect. } \\
\text { Dis., } 2002 .\end{array}$ & $\begin{array}{l}\text { Evaluate effectiveness of } \\
\text { HAART treatment by } M \text {. } \\
\text { haemophilum co-infection. }\end{array}$ & Case report & $\begin{array}{c}\text { PI } \\
\text { NRTI }\end{array}$ & 1 & $\begin{array}{l}\text { A local } M \text {. haemophilum skin } \\
\text { infection resolved as a result of } \\
\text { successful antiretroviral therapy } \\
\text { only. }\end{array}$ \\
\hline $\begin{array}{l}\text { Dronda et al. } \\
\text { Rev. Clin. } \\
\text { Esp., } 2000 .\end{array}$ & $\begin{array}{l}\text { Describe patient with } \\
\text { Mycobacterium xenopi lung } \\
\text { infection. }\end{array}$ & Case report & $\begin{array}{c}\text { PI } \\
\text { NRTI }\end{array}$ & 1 & $\begin{array}{l}\text { A possible latent infection } \\
\text { was expressed clinically after } \\
\text { immune reconstitution induced } \\
\text { by the treatment. }\end{array}$ \\
\hline
\end{tabular}

Protease inhibitor (PI); Nucleoside analog reverse-transcriptase inhibitors (NRTI), Highly active antiretroviral therapy (HAART). MAC: Mycobacterium avium complex.

rioration in patients with TB (Lawn, Bekler, Meller, 2000). Baalwa et al. (2008) discussed a possible limitation in the protective effects of HAART against TB recurrence and reiterated the need to consider TB chemoprophylaxis as a supplement to reduce TB in patients from endemic regions.

The initiation of HAART after starting TB treatment involves many variables such as drug tolerance, drug co-toxicities, pharmacokinetic drug interactions, polypharmacy impacts on adherence, high pill burden, and the immune reconstitution inflammatory syndrome (IRIS), thus complicating the management of co-infected individuals (Piggott, Karakousis, 2011; Wood, 2010). Perturbations of the innate and adaptive immune response to M. tuberculosis before and during antiretroviral therapy (ARV) may contribute to the immunopathology of tuberculosis-associated immune reconstitution inflammatory syndrome (TB-IRIS) (Oliver et al., 2010; Tadokera et al., 2011). Hypercytokinaemia appears to be involved with TB-IRIS, because higher interleukin (IL)-18, IL-6 and tumour necrosis factor (TNF) (Oliver et al., 2010; Tadokera et al., 2011) and type 1 effector T cell responses are noted in ARV-associated tuberculosis (Elliott et al., 2009).
Relevant reduction in the incidence of other mycobacteria such as Mycobacterium avium complex (MAC) has been reported among HIV-infected patients. The introduction of HAART, although partially explaining some of the decrease in MAC during a certain period, a significantly lower risk of MAC than expected remained (Kirk et al., 2000). A study showed that a 74\% reduction in the rate of new MAC infections occurred following widespread use of HAART (Tumbarello et al., 2001). The use of protease inhibitor-containing regimens was associated with a decreased risk of bacterial pneumonia (risk ratio [RR] 0.55, 95\% CI 0.31 to 0.94) (Sullivan et al., 2000).

Mycobacterium haemophilum was identified as the local agent of skin infection in an AIDS patient, and clinical cure was achieved only after reconstitution of immunity by HAART, although this has not been observed in clinical outcomes of patients with the invasive form of the disease (Paech et al., 2002). However, clinical manifestation was observed in patients presenting latent infection with Mycobacterium xenopi (Bachmeyer et al., 2002; Dronda et al., 2000; Manfredi et al., 2003) and Mycobacterium kansasii (Ito et al., 2009) after reconstitution 
of immunity by antiretroviral therapy. The isolation of pulmonary $M$. xenopi in an HIV-1 infected population is usually associated with severe immune suppression and the presence of other pathogens. In most cases, patients in use of HAART have potent immune reconstitution that is sufficient, dispensing with the need for antimycobacterial drugs. Mortality rates among these patients seems to be significantly lower than previously reported (Kerbiriou et al., 2003).

HIV-Mycobacterium leprae interaction is different from that described above. HIV infection has not been reported to increase susceptibility to leprosy or have a significant effect on the pathogenesis of neural or skin lesions. On the other hand, the initiation of HAART in HIV-leprosy patient has been reported to be associated with activation of subclinical infection and exacerbation of existing leprosy lesions. Chow et al. (2009) reported a case of IRIS in a patient co-infected with HIV and $M$. leprae, presenting as an exacerbation of Hansen's Disease where the patient's skin lesions progressed from borderline tuberculoid to lepromatous leprosy following ARV initiation. Other publications have also reported the presence of IRIS in HIV-Mycobacterium leprae patients (Couppie et al., 2004; Lawn, Wood, Lockwood, 2003; Pignatato et al., 2004; Visco-Comandini, et al., 2004).

\section{Antiretroviral drugs and protozoa agents (Table IV)}

Combination antiretroviral therapy has been able to modify the natural history of opportunistic diseases, such as cryptosporidiosis and microsporidiosis (Maggi et al., 2000). AIDS-related Enterocytozoon bieneusi and Cryptosporidium parvum may be cured following successful antiretroviral therapy (Miao et al., 2000), but infection eradication might not always be possible (Maggi et al., 2000). Protease inhibitors may be capable of eradicating Microsporidium and/or Criptosporidium, which are refractory to other treatments, and this effect may involve partial restoration of immune function due to the inhibition of HIV replication (Bobin et al., 1998). Miao et al. (2000) prospectively followed up HIV-positive patients with diarrheal symptoms caused by cryptosporidia or microsporidia and observed that patients who responded successfully to HAART eradicated both organisms promoting improved symptoms within one month of therapy. Complete eradication of the organisms however, was only observed after 6 months of treatment. Combination antiretroviral therapy that includes a PI may restore immunity and result in complete clinical, microbiological, and histological responses to Enterocytozoon bieneusi and Cryptosporidium parvum in HIV-1 infected individuals
(Carr et al., 1998). Findings show rapid repopulation of the intestinal mucosa with CD4+ T cells after initiation of HAART, which can effectively restore mucosal immunity, leading to the eradication of Cryptosporidium parvum (Carr et al., 1998). Indinavir directly affects the cycle of C. parvum, evidenced by marked reduction in oocyst shedding and number of intracellular parasites on in vitro and in vivo models (Mele et al., 2003).

In 2001, Casado et al. determined the evolution of visceral leishmaniasis (VL) in 10 consecutive patients co-infected with HIV, taking into account the decline in the incidence of opportunistic infections after the introduction of protease inhibitor therapy. Giudice et al, (2002) estimated the incidence of HIV-Leishmania coinfections in a French hospital, and showed a decreased from $11.6 \pm$ 1.2 per 10,000 persons-years before 1996 to $6.3 \pm 0.7$ per 10,000 persons-years after 1996, the year when HAART was introduced in France. Factors other than restoration of immune function might also account for the decline in the incidence of VL. PIs have shown antimicrobial properties, such as anticandidal and antitoxoplasmic activities, in vitro.

Some studies have reported antiprotozoal activity of HAART in Leishmania (Araújo et al., 2011; Kumar et al., 2008; Santos et al., 2009; Savoia, Allice, Tovo, 2005; Valdivieso et al., 2010). AZT significantly decreased the number of Leishmania parasites due to its toxicity and caused morphometric alterations such as an increase in width of the body, cytoplasmic granulation and vacuolization (Araújo et al., 2011). PIs such as ritonavir, indinavir and saquinavir have reduced the number of Leishmania promastigotes in vitro (Savoia, Allice, Tovo, 2005). Furthermore, PIs seem to reduce the intracellular growth of Leishmania parasites in human primary monocytederived macrophages (MDMs) coinfected with HIV-1 (Trudel et al., 2008) and can also induce oxidative stressmediated, caspase-independent apoptosis in Leishmania amastigotes (Kumar et al., 2010). Valdivieso et al. (2010) reported an antiproliferative effect on Leishmania sp. promastigotes, axenic amastigotes and co-infected HIV/ Leishmania monocytes and amastigotes of Leishmania per macrophage by saquinavir mesylate and nelfinavir. This outcome appears to be the result of cell division block. In addition, PIs can promote profound changes in Leishmania ultrastructure such as cytoplasm shrinking, increase in the number of lipid inclusions with some cells presenting the nucleus closely wrapped by endoplasmic reticulum resembling an autophagic process, as well as chromatin condensation, suggestive of apoptotic death (Santos et al., 2009).

Analysis of therapy-induced changes in the mucosal 
TABLE IV - Characteristics of studies included in the systematic review, on antiretroviral agents and protozoa

\begin{tabular}{|c|c|c|c|c|c|}
\hline Source & Aim & Study design & Drug groups & Patients (n) & Conclusion \\
\hline $\begin{array}{l}\text { Miao et al. } \\
J A I D S, 2000 .\end{array}$ & $\begin{array}{l}\text { Determine whether the } \\
\text { parasites cryptosporidia and } \\
\text { microsporidia were effectively } \\
\text { eradicated or supply } \\
\text { suppressed after HAART. }\end{array}$ & Prospective & $\begin{array}{l}\text { NRTI } \\
\text { PI }\end{array}$ & 6 & $\begin{array}{l}\text { AIDS-related cryptosporidiosis } \\
\text { and microsporidiosis can be } \\
\text { cured following successful } \\
\text { antiretroviral therapy }\end{array}$ \\
\hline $\begin{array}{l}\text { Bobin et al. } \\
\text { Path. Biol., } \\
1998 .\end{array}$ & $\begin{array}{l}\text { Evaluate ARV effect on } \\
\text { evolution of diarrhea caused } \\
\text { by Microsporidium and } \\
\text { Criptosporidium in HIV } \\
\text { patients. }\end{array}$ & Prospective & PI & 20 & $\begin{array}{l}\text { PI may be capable of eradicating } \\
\text { Microsporidium and/or } \\
\text { Criptosporidium infection } \\
\text { refractory to other treatments. }\end{array}$ \\
\hline $\begin{array}{l}\text { Carr et al. } \\
\text { Lancet, } 1998 .\end{array}$ & $\begin{array}{l}\text { Demonstrate that combination } \\
\text { PI and NRTIs may improve } \\
\text { immunity with regard to } E \text {. } \\
\text { bieneusi and } C \text {. parvum. }\end{array}$ & Prospective & $\begin{array}{l}\text { NRTI } \\
\text { PI }\end{array}$ & 9 & $\begin{array}{l}\text { This combination can restore } \\
\text { immunity to E.bieneusi or } \\
\text { C. parvum in HIV-1 infected } \\
\text { individuals. }\end{array}$ \\
\hline $\begin{array}{l}\text { Maggi et al. } \\
\text { Eur. J. Clin. } \\
\text { Microbiol. } \\
\text { Infect. Dis., } \\
2000 .\end{array}$ & $\begin{array}{l}\text { Evaluate response to } \\
\text { antimicrobial treatment } \\
\text { of HIV-1 associated } \\
\text { microsporidiosis and } \\
\text { cryptosporidiosis in patients } \\
\text { with or without previous } \\
\text { antiretroviral treatment. }\end{array}$ & Retrospective & $\begin{array}{c}\text { NRTI } \\
\text { PI }\end{array}$ & 50 & $\begin{array}{l}\text { Combination antiretroviral } \\
\text { therapy may be able to greatly } \\
\text { modify the course of these } \\
\text { diseases in patients infected with } \\
\text { HIV-1. }\end{array}$ \\
\hline
\end{tabular}

Protease inhibitor (PI); Highly active antiretroviral therapy (HAART); Nucleoside analog reverse-transcriptase inhibitors (NRTI); Antiretroviral therapy (ARV).

immune response of these patients may provide significant clues to the mechanisms involved in the control of enteric opportunistic agents (Schimdt et al., 2001). Similarly, persistent $\mathrm{CD} 8^{+} \mathrm{T}$-cells and macrophage infiltrate plus the rapid relapse time in patients with declining $\mathrm{CD}^{+} \mathrm{T}$-cells counts suggest that neither infection was eradicated (Carr et al., 2000).

Restoration of immune responses to Toxoplasma gondii, a major opportunistic pathogen in patients with AIDS, has also been reported in patients receiving HAART (Derouin and Santillana-Hayat, 2000). Pozio and Morales (2005) have reported that the use of PIs resulted in marked decrease in toxoplasmic encephalitis among HIV-positive individuals.

Furco et al. (2008) showed that specific immune reconstitution against $T$. gondii occurred in most HIV-infected patients with a low baseline CD4+ T-cell count after 12 months of HAART. However, a significant proportion of these patients did not present a normal lymphoproliferative response or IFN- $\gamma$ production to the Toxoplasma antigen. These data will also promote better understanding of the determinants of restoration of $T$. gondii-specific immune responses in patients with AIDS starting on HAART. Derouin and Santillana-Hayat (2000) showed that nucleoside analogs had no effect on T.gondii growth in vitro, whereas ritonavir and nelfinavir were inhibitory for Toxoplasma.

\section{CONCLUDING REMARKS}

Current finding are highly relevant for clinical medicine and may serve to reduce the number of prescribed drugs thereby improving the quality of life of patients with opportunistic diseases. The present systematic review identified several opportunistic agents of the oral cavity subjected to the positive activities of HAART thus decreasing the number of fungi, favoring SAP inhibition, and improving laboratory and immunological parameters. In the case of viruses, antiretroviral therapy may be 
beneficial for patients co-infected by HIV, HHV-8, EBV, $\mathrm{HBV}$, parvovirus B19 and CMV. The incidence of Mycobacterium tuberculosis, Mycobacterium avium complex, Microsporidium and/or Criptosporidium, refractory to other treatments was significantly reduced. Protease inhibitors are of paramount importance among those drugs currently used in HAART.

\section{REFERENCES}

ABBENANTE, G.; FAIRLIE, D.P. Protease inhibitors in the clinic. Med. Chem., v.1, n.1, p.71-104. 2005.

ANDREWS, K.T.; FAIRLIE, D.P.; MADALA, P.K.; RAY, J.; WYATT, D.M.; HILTON, P.M.; MELVILLE, L.A.; BEATTIE, L.; GARDINER, D.L.; REID, R.C.; STOERMER, M.J.; SKINNER-ADAMS, T.; BERRY, C.; MCCARTHY, J.S. Potencies of human immunodeficiency virus protease inhibitors in vitro against murine malaria. Antimicrob. Agents Chemother., v.50, n.2, p.639-648, 2006.

ARAÚJO, C.A.; ARAÚJO, A.A.; BATISTA, C.L.; OLIVEIRA, M.A.; OLIVEIRA, V.; LINO JUNIOR, R.S.; VINAUD, M.C.; BEZERRA, J.C. Morphological alterations and growth inhibition of Leishmania (L.) amazonensis promastigotes exposed to zidovudine (AZT). Parasitol. Res., v.108, n.3, p.547-551, 2011.

ARRIBAS, J.R.; HERNÁNDEZ-ALBUJAR, S.; GONZÁLEZGÁRCIA, J.J.; PEÑA, J.M.; GONZALEZ, A.; CAÑEDO, T.; MADERO, R.; VASQUEZ, J.J.; POWDERLY, W.G. Impact of protease inhibitor therapy on HIV-related oropharyngeal candidiasis. AIDS, v.14, n.8, p.979-985, 2000.

BAALWA, J.; MAYANJA-KIZZA, H.; KAMYA, M.R.; JOHN, L.; KAMBUGU, A.; COLEBUNDERS, R. Worsening and unmasking of tuberculosis in HIV-1 infected patients after initiating highly active anti-retroviral therapy in Uganda. Afr. Health Sci., v.8, n.3, p.190-195, 2008.

BACHMEYER, C.; BLUM, L.; STELIANIDES, S.; BENCHAA, B.; GRUAT, N.; DANNE, O. Mycobacterium xenopi pulmonary infection in an HIV infected patient under highly active antiretroviral treatment. Sex Transm. Infect., v.78, n.1, p.60-61, 2002.
BEKTIĆ, J.; LELL, C.P.; FUCHS, A.; STOIBER, H.; SPETH, C.; LASS-FLÖRL, C.; BORG-VON ZEPELIN, M.; DIERICH, M.P.; WÜRZNER, R. HIV protease inhibitors attenuate adherence of Candida albicans to epithelial cells in vitro. FEMS Immunol. Med. Microbiol., v.31, n.1, p.6571, 2001.

BENHAMOU, Y.; BOCHET, M.; THIBAULT, V.; CALVEZ, V.; FIEVET, M.H.; VIG, P.; GIBBS, C.S.; BROSGART, C.; FRY, J.; NAMINI, H.; KATLAMA, C.; POYNARD, T. Safety and efficacy of adefovir dipivoxil in patients co-infected with HIV-1 and lamivudine-resistant hepatitis B virus: an open-label pilot study. Lancet, v.358, n.9283, p. 718-723, 2001.

BLANCO, M.T.; HURTADO, C.; PÉREZ-GIRALDO, C.; MORÁN, F.J.; GONZÁLEZ-VELASCO, C.; GÓMEZGARCÍA, A.C. Effect of ritonavir and saquinavir on Candida albicans growth rate and in vitro activity of aspartyl proteinases. Med. Mycol., v.41, n.2, p.167-170, 2003.

BOBIN, S.; BOUHOUR, D.; DURUPT, S.; BOIBIEUX, A.; GIRAULT, V.; PEYRAMOUND, D. Des infections à microsporidies et/ou cryptosporidies chez des patients VIH-séropositifs. Pathol. Biol., v.46, n.6, p.418-419, 1998.

BORGES, L.H.B.; VILLAS BOAS, L.S.; WARRENSANTORO, S.H.; ESTEVAM, M.P.; UIP, D.E.; SAVALLI, C.; CURI, M.; PANNUTI, C.S. Effect of highly active antiretroviral therapy on cytomegalovirus antigenaemia in AIDS patients. Int. J. STD AIDS, v.12, n.4, p.234-238, 2001.

BORG-VON ZEPELIN, M.; MEYER, I.; THOMSSEN, R.; WÜRZNER, R.; SANGLARD, D.; TELENTI, A.; MONOD, M. HIV-Protease inhibitors reduce cell adherence of Candida albicans strains by inhibition of yeast secreted aspartic proteases. J. Invest. Dermatol., v.113, n.5, p.747$751,1999$.

BRAGA-SILVA, L.A.; MOGAMI, S.S.; VALLE, R.S.; SILVANETO, I.D.; SANTOS, A.L. Multiple effects of amprenavir against Candida albicans. FEMS Yeast Res., v.10, n.2, p.221-224, 2010.

CARR, A.; MARRIOTT, D.; FIEL, A.; VASAK, E.; COOPER, D.A. Treatment of HIV-1-associated microsporidiosis and cryptosporidiosis with combination antiretroviral therapy. Lancet, v.351, n.9098, p.256-261, 1998. 
CASADO, J.L.; LOPEZ-VELEZ, R.; PINTADO, V.; QUEREDA, C.; ANTELA, A.; MORENO, S. Relapsing visceral leishmaniasis in $\mathrm{HIV}$-infected patients undergoing successful protease inhibitor therapy. Eur. J. Clin. Microbiol. Infect. Dis., v.20, n.3, p.202-205. 2001.

CASSONE, A.; DE BERNARDIS, F.; TOROSANTUCCI, A.; TACCONELLI, E.; TUMBARELLO, M.; CAUDA, $\mathrm{R}$. In vitro and in vivo anticandidal activity of human immunodeficiency virus protease inhibitors. J. Infect. Dis., v.180, n.2, p.448-453, 1999.

CASSONE, A.; TACCONELLI, E.; BERNARDIS, F.; TUMBARELLO, M.; TOROSANTUCCI, A.; CHIANI, P.; CAUDA, R. Antiretroviral therapy with protease inhibitors has an early, immune reconstitution-independent beneficial effect on Candida virulence and oral candidiasis in human immunodeficiency virus-infected subjetcs. J. Infect. Dis., v.185, n.2, p.188-195, 2002.

CHOW, D.; OKINAKA, L.; SOUZA, S.; SHIKUMA, C.; TICE, A. Hansen's disease with HIV: a case of immune reconstitution disease. Hawaii Med. J., v.68, n.2, p.27-29, 2009.

COUPPIÉ, P.; ABEL, S.; VOINCHET, H.; ROUSSEL, M.; HÉLÉNON, R.; HUERRE, M.; SAINTE-MARIE, D.; CABIÉ, A. Immune reconstitution inflammatory syndrome associated with HIV and leprosy. Arch. Dermatol., v.140, n.8, p.997-1000, 2004.

DEAL, C.; AJANA, F.; CANVA, V.; MOUTON, Y.; YAZDANPANAH, P.; WATTRÉ, L.; BOCKET, L. Intérêt de la quantification par PCR de I'and du VHB chez les patients traités par lamivudine. Ann. Biol. Clin., v.60, n.5, p.581-588, 2002.

DEAYTON, J.; MOCROFT, A.; WILSON, P.; EMERY, V.C.; JOHNSON, M.A.; GRIFFITHS, P.D. Loss of cytomegalovirus (CMV) viraemia following highly active antiretroviral therapy in the absence of specific anti-CMV therapy. AIDS, v.13, n.10, p.1203-1206, 1999.

DEL GIUDICE, P.; MARY-KRAUSE, M.; PRADIER, C.; GRABAR, S.; DELLAMONICA, P.; MARTY, P.; GASTAUT, J.A.; COSTAGLIOLA, D.; ROSENTHAL, E. Impact of highly active antiretroviral therapy on the incidence of visceral leishmaniasis in a french cohort of patients infected with human immunodeficiency virus. $J$. Infect. Dis., v.186, n.9, p.1366-1370, 2002.
DELPIERRE, C.; LAUWERS-CANCES, V.; PUGLIESE, P.; POIZOT-MARTIN, I.; BILLAUD, E.; DUVIVIER, C.; YAZDANPANAH, Y.; CUZIN, L.; NADIS GROUP. Characteristics trends, mortality and morbidity in persons newly diagnosed HIV positive during the last decade: the profile of new HIV diagnosed people. Eur. J. Public Health, v.18, n.3, p.345-347, 2008.

DEROUIN, F.; SANTILLANA-HAYAT, M. Anti-Toxoplasma activities of antiretroviral drugs and interactions with pyrimethamine and sulfadiazine in vitro. Antimicrob. Agents Chemother., v.44, n.9, p.2575-2577, 2000.

DRONDA, F.; NAVAS, E.; PINTADO, V.; GÓMEZMAMPASO, E. Mycobacterium xenopi pulmonary infection after starting high efficiency treatment with indinavir. Rev. Clin. Esp., v.200, n.6, p.347-348, 2000.

ELLIOTT, J.H.; VOHITH, K.; SARAMONY, S.; SAVUTH, C.; DARA, C.; SARIM, C.; HUFFAM, S.; OELRICHS, R.; SOPHEA, P.; SAPHONN, V.; KALDOR, J.; COOPER, D.A.; CHHI VUN, M.; FRENCH, M.A. Immunopathogenesis and diagnosis of tuberculosis and tuberculosis-associated immune reconstitution inflammatory syndrome during early antiretroviral therapy. J. Infect. Dis., v.200, n.11, p.1736$1745,2009$.

EVERETT, D.B.; MUKAKA, M.; DENIS, B.; GORDON, S.B.; CARROL, E.D.; VAN OOSTERHOUT, J.J.; MOLYNEUX, E.M.; MOLYNEUX, M.; FRENCH, N.; HEYDERMAN, R.S. Ten years of surveillance for invasive Streptococcus pneumoniae during the era of antiretroviral scale-up and cotrimoxazole prophylaxis in Malawi. PLoS One, v.6, n.3, p.e17765, 2011.

FALKENSAMMER, B.; PILZ, G.; BEKTIC, J.; IMWIDTHAVA, P.; JÖHRER, K.; SPETH, C.; LASS-FLÖRL, C.; DIERICH, M.P.; WÜRZNER, R. Absent reduction by HIV protease inhibitors of Candida albicans adhesion to endothelial cells. Mycoses, v.50, n.3, p.172-177, 2007.

FURCO, A.; CARMAGNAT, M.; CHEVRET, S.; GARIN, Y.J.F.; PAVIE, J.; CASTRO N.; CHARRON, D.; DEROUIN, F.; RABIAN, C.; MOLINA, J.M. Restoration of Toxoplasma gondii-specific immune responses in patients with AIDS starting HAART. AIDS, v.22, n.16, p.2087-2096, 2008. 
FRANZETTI, F.; GRAS SINI, A.; PIAZZA, M.; DEGL'INNOCENTI, M.; BANDERA, A.; GAZZOLA, L.; MARCHETTI, G.; GORI, A. Nosocomial bacterial pneumonia in HIV-infected patients: risk factors for adverse outcome and implications for rational empiric antibiotic therapy. Infection, v.34, n.1, p.9-16, 2006.

GRUBER, A.; SPETH, C.; LUKASSER-VOGL, E.; ZANGERLE, R.; BORG-VON ZEPELIN, M.; DIERICH, M.P.; WÜRZNER, R. Human immunodeficiency virus type 1 protease inhibitor attenuates Candida albicans virulence properties in vitro. Immunopharmacology, v.41, n.3, p.227234, 1999.

HARRINGTON, W.; SIECZKOWSKI, L.; SOSA, C.; CHANA-SUE, S.; CAI, J.P.; CABRAL, L.; WOOD, C. Activation of HHV-8 by HIV-1 tat. Lancet, v.349, n.9054, p.774-775, 1997.

HOCQUELOUX, L.; AGBALIKA, F.; OKSENHENDLER, E.; MOLINA, J.M. Long-term remission of an AIDS-related primary effusion lymphoma with antiviral therapy. AIDS, v.15, n.2, p.280-282, 2001.

HOEGL, L.; THOMA-GREBER, E.; RÖCKEN, M.; KORTING, H.C. HIV protease inhibitors influence the prevalence of oral candidosis in HIV-infected patients: a 2-year study. Mycoses, v.41, n.7-8, p.321-325, 1998.

ITO, M.; KOMATSU, Y.; USHIKI, A.; YAMAZAKI, Y.; $\mathrm{KUBO}, \mathrm{K}$. An AIDS patients with immune reconstituition inflammatory syndrome due to pulmonary Mycobacterium kansasii infection during antiretroviral therapy. J. Infect. Chemother., v.15, n.5, p.331-334, 2009.

KABBESH, M.; KOOMER, A.; MOLTENI, A.; AMAJOVI, R.; QUINN, T.; HERNDON, B. The effect of treatment with a protease inhibitor on mycobacterial infection. Diagn. Microbiol. Infect. Dis., v.51, n.4, p.251-258, 2005.

KERBIRIOU, L.; USTIANOWSKI, A.; JOHNSON, M.A.; GILLESPIE, S.H.; MILLER, R.F.; LIPMAN, M.C. Human immunodeficiency virus type 1-related pulmonary Mycobacterium xenopi infection: a need to treat? Clin. Infect. Dis., v.37, n.9, p.1250-1254, 2003.
KIRK, O.; GATELL, J.M.; MOCROFT, A.; PEDERSEN, C.; PROENCA, R.; BRETTLE, R.P.; BARTON, S.E.; SUDRE, P.; PHILLIPS, A.N. Infections with Mycobacterium tuberculosis and Mycobacterium avium among HIVinfected patients after the introduction of highly active antiretroviral therapy. Euro SIDA Study Group JD. Am. J. Respir. Crit. Care Med., v.162, n.3, p.865-872, 2000.

KORTING, H.C.; SCHALLER, M.; EDER, G.; HAMM, G.; BÖHMER, U.; HUBE, B. Effects of the human immunodeficiency virus (HIV) proteinase inhibitors saquinavir and indinavir on in vitro activities of secreted aspartyl proteinases of Candida albicans isolates from HIVinfected patients. Antimicrob. Agents Chemother., v.43, n.8, p.2038-2042, 1999.

KUMAR, P.; LODGE, R.; TRUDEL, N.; OUELLET, M.; OUELLETTE, M.; TREMBLAY, M.J. Nelfinavir, an HIV1 protease inhibitor, induces oxidative stress-mediated, caspase-independent apoptosis in Leishmania amastigotes. PLoS Negl. Trop. Dis., v.4, n.3, p.e642, 2010.

KUMAR, S.P.; MEDHI, S.; ASIM, M.; DAS, B.C.; GONDAL, R.; KAR, P. Evaluation of adefovir \& lamivudine in chronic hepatitis B: correlation with HBV viral kinetic, hepaticnecro inflammation \& fibrosis. Indian J. Med. Res., v.133, n.1, p.50-56, 2011.

LARSEN, I.K.; GRADEL, K.O.; HELMS, M.; HORNSTRUP, M.K.; JÜRGENS, G.; MENS, H.; ROSAGER, C.L.; CLAUSEN, T.H.; KRONBORG, G.; NIELSEN, H. Nontyphoidal Salmonella and Campylobacter infections among HIV-positive patients in Denmark. Scand. J. Infect. Dis., v.43, n.1, p.3-7, 2011.

LAWN, S.D.; BEKLER, L.G.; MELLER, R.F. Immune reconstitution disease associated with mycobacterial infections in HIV-infected individuals receiving antiretrovirals. Lancet Infect. Dis., v.5., n.6, p.361-373, 2010.

LAWN, S.D.; WOOD, C.; LOCKWOOD, D.N. Borderline tuberculoid leprosy: an immune reconstitution phenomenon in a human immunodeficiency virus-infected person. Clin. Infect. Dis., v.36, n.1, p.5-6, 2003.

LEBBE, C.; BLUM, L.; PELLET, C.; BLANCHARD, G.; VÉROLA, O.; MOREL, P.; DANNE, O.; CALVO, F. Clinical and biological impact of antiretroviral therapy with protease inhibitors on HIV-related Kaposi's sarcoma. AIDS, v.12, n.7, p.45-49, 1998. 
LEONE, S.; NICASTRI, E.; GIGLIO, S.; NARCISO, P.; IPPOLITO, G.; ACONE, N. Immune reconstitution inflammatory syndrome associated with Mycobacterium tuberculosis infection: a systematic review. Int. J. Infect. Dis., v.14, n.4, p.283-291, 2010.

LI, T.S.; TUBIANA, R.; FILLET, A.M.; AUTRAN, B.; KATLAMA, C. Negative result of cytomegalovirus blood culture with restoration of CD4+ T-cell reactivity to cytomegalovirus after HAART in an HIV-1-infected patient. J. Acquir. Immune Defic. Syndr. Hum. Retrovirol., v.20, n.5, p.514-515, 1999.

MACURA, A.; BORT, A.; POSTAWA-KLOSINSKA, B.; $\mathrm{MACH}, \mathrm{T}$. Various patterns of oral mucosa candidiasis treatment in HIV patients. Folia Med. Cracov., v.43, n.1-2, p.69-77, 2002.

MAGGI, P.; LAROCCA, A.M.V.; QUARTO, M.; SERIO, G.; BRANDONISIO, O.; ANGARANO, G.; PASTORE, G. Effect of antiretroviral therapy on cryptosporidiosis and microsporidiosis in patients infected with human immunodeficiency virus type 1. Eur. J. Clin. Microbiol. Infect. Dis., v.19, n.3, p.213-217, 2000.

MANFREDI, R.; NANETTI, A.; TADOLINI, M.; CALZA, L.; MORELLI, S.; FERRI, M.; MARINACCI, G. Role of Mycobacterium xenopi disease in patients with HIV infection at the time of highly active antiretroviral therapy (HAART). Comparison with the pre-Haart period. Tuberculosis (Edinb), v.83, n.5, p.319-328, 2003.

MAYAUD, C.; PARROT, A.; CADRANEL, J. Pyogenic bacterial lower respiratory tract infection in human immunodeficiency virus-infected patients. Eur. Respir. J., v.20, n.36, p.28-30, 2002.

MELE, R.; MORALES, M.A.G.; TOZINI, F.; POZIO, E. Indinavir reduces Crypstosporidium parvum infection in both in vitro and in vivo models. Int. J. Parasitol., v.33, n.7, p.757-764, 2003.

MIAO, Y.M.; AWAD-EL-KARIEM, F.M.; FRANZEN, C.; ELLIS, D.S.; MULLER, A.; COUNIHAN, H.M.; HAYES, P.J.; GAZZARD, B.G. Eradication of Cryptosporidia and Microsporidia following successful antiretroviral therapy. J. Acquir. Immune Defic. Syndr., v.25, n.2, p.124-129. 2000.
MigliorATI, C.A.; BIRMAN, E.G.; CURY, A.E.; LAUDERDALE, F. Oropharyngeal candidiasis in HIVinfected patients under treatment with protease inhibitors. Oral Surg. Oral Med. Oral Pathol. Oral Radiol. Endod., v.98, n.3, p.301-310, 2004.

MONOD, M.; BORG-VON ZEPELIN, M.; TELENTI, A.; SANGLARD, D. The inhibition of Candida-albicanssecreted aspartic proteases by three different HIV protease inhibitors. Dermatology, v.198, n.4, p.412-414, 1999.

MYLONAKIS, E.; DICKINSON, B.P.; MILENO, M.D.; FLANIGAN, T.; SCHIFFMAN, F.J.; MEGA, A.; RICH, J.D. Persistent parvovirus B19 related anemia of seven years' duration in an HIV-infected patient: complete remission associated with highly active antiretroviral therapy. Am. J. Hematol., v.60, n.2, p.164-166, 1999.

NAKAJIMA-SHIMADA, J.; AOKI, T. Inhibition by 3'-azido3'-deoxythymidine (AZT) of Trypanosoma cruzi growth in mammalian cells and a possible mechanism of action. $A d v$. Exp. Med. Biol., v.431, p.719-722, 1998.

NUNES, M.C.; VON GOTTBERG, A.; DE GOUVEIA, L.; COHEN, C.; MOORE, D.P.; KLUGMAN, K.P.; MADHI, S.A. The impact of antiretroviral treatment on the burden of invasive pneumococcal disease in South African children: a time series analysis. AIDS, v.25, n.4, p.453-462, 2011.

OLIVER, B.G.; ELLIOTT, J.H.; PRICE, P.; PHILLIPS, M.; SAPHONN, V.; VUN, M.C.; KALDOR, J.M.; COOPER, D.A.; FRENCH, M.A. Mediators of innate and adaptive immune responses differentially affect immune restoration disease associated with Mycobacterium tuberculosis in HIV patients beginning antiretroviral therapy. J. Infect. Dis., v.202, n.11, p.1728-1737, 2010.

PAECH, V.; LORENZEN, T.; VON KROSIGK, A.; VON STEMM, A.; MEIGEL, W.M.; STOEHR, A.; RÜSCHGERDES, S.; RICHTER, E.; PLETTENBERG, A. Remission of cutaneous Mycobacterium haemophilum infection as a result of antiretroviral therapy in a human immunodeficiency virus-infected patient. Clin. Infect. Dis., v.34, n.7, p.1017-1019, 2002.

PARIKH, S.; GUT, J.; ISTVAN, E.; GOLDBERG, D.E.; HAVLIR, D.V.; ROSENTHAL, P.J. Antimalarial activity of human immunodeficiency virus type 1 protease inhibitors. Antimicrob. Agents Chemother., v.49, n.7, p.2983-2985, 2005. 
PERILLO, R.; SCHIFF, E.; YOSHIDA, E.; STATLER, A.; HIRSCH, K.; WRIGHT, T.; GUTFREUND, K.; LAMY, P.; MURRAY, A. Adefovir dipivoxil for treatment of lamivudine-resistant hepatitis B mutants. Hepatology, v.32, n.1, p.129-134, 2000.

PIGGOTT, D.A.; KARAKOUSIS, P.C. Timing of antiretroviral therapy for HIV in the setting of TB treatment. Clin. Dev. Immunol., v.2011, n.2011, p.103917, 2011.

PIGNATARO, P.; ROCHAADA, S.; NERY, J.A.; MIRANDA, A.; SALES, A.M.; FERRREIRA, H.; VALENTIM, V.; SUFFYS, P.N. Leprosy and AIDS: two cases of increasing inflammatory reactions at the start of highly active antiretroviral therapy. Eur. J. Clin. Microbiol. Infect. Dis., v.23, n.5, p.408-411, 2004.

POMARICO, L.; CERQUEIRA, D.F.; DEARAUJO SOARES, R.M.; DE SOUZA, I.P.; DE ARAUJO CASTRO, G.F.; SOCRANSKY, S.; HAFFAJEE, A.; TELES, R.P. Associations among the use of highly active antiretroviral therapy, oral candidiasis, oral Candida species and salivary immunoglobulin A in HIV-infected children. Oral Surg. Oral Med. Oral Pathol. Oral Radiol. Endod., v.108, n.2, p.203-210, 2009.

POZIO, E.; MORALES, M.A.G. The impact of HIV-protease inhibitors on opportunistic parasites. Trends Parasitol., v.21, n.2, p.58-63, 2005.

REDMOND, A.M.; SKINNER-ADAMS, T.; ANDREWS, K.T.; GARDINER, D.L.; RAY, J.; KELLY, M.; MCCARTHY, J.S. Antimalarial activity of sera from subjects taking HIV protease inhibitors. AIDS, v.21, n.6., p.763-765, 2007.

REIJNDERS, J.G.; PERQUIN, M.J.; ZHANG, N.; HANSEN, B.E.; JANSSEN, H.L. Nucleos(t)ide analogues only induce temporary hepatitis B e antigen seroconversion in most patients with chronic hepatitis B. Gastroenterology, v.139, n.2, p.491-498, 2010.

SANTOS, L.O.; MARINHO, F.A.; ALTOÉ, E.F.; VITÓRIO, B.S.; ALVES, C.R.; BRITTO, C.; MOTTA, M.C.; BRANQUINHA, M.H.; SANTOS, A.L.; D'AVILALEVY, C.M. HIV aspartyl peptidase inhibitors interfere with cellular proliferation, ultrastructure and macrophage infection of Leishmania amazonensis. PLoS One, v.4, n.3, p.e4918, 2009.
SAVOIA, D.; ALLICE, T.; TOVO, P.A. Antileishmanial activity of HIV protease inhibitors. Int. J. Antimicrob. Agents, v.26, n.1., p.92-94, 2005.

SCHMIDT, W.; WAHNSCHAFFE, U.; SCHÄFER, M.; ZIPPEL, T.; ARVAND, M.; MEYERHANS, A.; RIECKEN, E.O.; ULLRICH, R. Rapid increase of mucosal CD4 T cells followed by clearance of intestinal crytosporidiosis in an AIDS patient receiving highly active antiretroviral therapy. Gastroenterology, v.120, n.4, p.984-987, 2001.

SHINKAI, N.; TANAKA, Y.; ORITO, E.; ITO, K.; OHNO, T.; HIRASHIMA, N.; HASEGAWA, I.; SUGAUCHI, F.; UEDA, R.; MIZOKAMI, M. Measurement of hepatitis B virus core-related antigen as predicting factor for relapse after cessation of lamivudine therapy for chronic hepatitis B virus infection. Hepatol. Res., v.36, n.4, p.272-276, 2006.

SULLIVAN, J.H.; MOORE, R.D.; KERULY, J.C.; CHAISSON, R.E. Effect of antiretroviral therapy on the incidence of bacterial pneumonia in patients with advanced HIV infection. Am. J. Respir. Crit. Care Med., v.162, n.1, p.6467,2000

SUNG, J.J.; WONG, M.L.; BOWDEN, S.; LIEW, C.T.; HUI, A.Y.; WONG, V.W.; LEUNG, N.W.; LOCARNINI, S.; CHAN, H.L. Intrahepatic hepatitis B virus covalently closed circular DNA can be a predictor of sustained response to therapy. Gastroenterology, v.128, n.7, p.1890-1897, 2005.

TADOKERA, R.; MEINTJES, G.; SKOLIMOWSKA, K.H.; WILKINSON, K.A.; MATTHEWS, K.; SELDON, R.; CHEGOU, N.N.; MAARTENS, G.; RANGAKA, M.X.; REBE, K.; WALZL, G.; WILKINSON, R.J. Hypercytokinaemia accompanies HIV-tuberculosis immune reconstitution inflammatory syndrome. Eur. Respir. J., v.37, n.5, p.1248-1259, 2011

TRUDEL, N.; GARG, R.; MESSIER, N.; SUNDAR, S.; OUELLETTE, M.; TREMBLAY, M.J. Intracellular survival of Leishmania species that cause visceral leishmaniasis is significantly reduced by HIV-1 protease inhibitors. J. Infect. Dis., Oxford, v.198, n.9, p.1292-1299, 2008.

TSANG, C.S.; HONG, I. HIV protease inhibitors differentially inhibit adhesion of Candida albicans to acrylic surfaces. Mycoses, v.53, n.6, p.488-494, 2009. 
TUMBARELLO, M.; TACCONELLI, E.; DE DONATI, K.G.; BERTAGNOLIO, S.; LONGO, B.; ARDITO, F.; FADDA, G.; CAUDA, R. Changes in incidence and risk factors of Mycobacterium avium complex infections in patients with AIDS in the ERA of new antiretroviral therapies. Eur. J. Clin. Microbiol. Infect. Dis., v.20, n.7, p.498-501, 2001.

TUMBARELLO, M.; TACCONELLI, E.; DONATI, K.; CAUDA, R. HIV-associated bacterial pneumonia in the era of highly active antiretroviral therapy. J. Acquir. Immune Defic. Syndr., v.20, n.2, p.208-209, 1999.

TUMBARELLO, M.; TACCONELLI, E.; DONATI, K.G.; CITTON, R.; LEONE, F.; SPANU, T.; CAUDA, R. HIVassociated bacteremia: How it has changed in the highly active antiretroviral therapy (HAART) era. J. Acquir. Immune Defic. Syndr., v.23. n.2, p.145-151, 2000.

VALDIVIESO, E.; RANGEL, A.; MORENO, J.; SAUGAR, J.M.; CAÑAVATE, C.; ALVAR, J.; DAGGER, F. Effects of HIV aspartyl-proteinase inhibitors on Leishmania sp. Exp. Parasitol., v.126, n.4, p.557-563, 2010.

VISCO-COMANDINI, U.; LONGO, B.; CUZZI, T.; PAGLIA, M.G.; ANTONUCCI, G. Tuberculoid leprosy in a patient with AIDS: a manifestation of immune restoration syndrome. Scand. J. Infect. Dis., London, v.36, n.11-12, p.881-883, 2004.
WARE, A.J.; MOORE, T. Resolution of chronic parvovirus B19induced anemia, by use highly active antiretroviral therapy, in a patient with acquired immunodeficiency syndrome. Clin. Infect. Dis., v.32, n.7, p.122-123, 2001.

WIT, F.W. N.M.; SOL, C.J.A.; RENWICK, N.; ROOS, M.T.L.; PALS, S.T.; Van LEEWEN, R.; GOUDSMIT, J.; REISS, P. Regression of AIDS-related Kaposi's sarcoma associated with clearance of human herpesvirus- 8 from peripheral blood mononuclear cells following initiation of antiretroviral therapy. AIDS, v.12, n.2, p.218-219, 1998.

WOOD, R. When to start antiretroviral therapy in children with TB? Expert Rev. Anti. Infect. Ther., v.8, n.10, p.1101-1104, 2010.

WORLD HEALTH ORGANiZATION. Antiretroviral therapy for HIV infection in adults and adolescents: recommendations for a public health approach. Geneve, 2006. 134 p.

YANG, Y.; LO, H.; HUNG, C.; LI, Y. Effect of prolonged HAART on oral colonization with Candida and candidiasis. BMC Infect. Dis., v.6, n.8, p.1-4, 2006.

Received for publication on $20^{\text {th }}$ May 2011 Accepted for publication on $19^{\text {th }}$ January 2012 
